\title{
High Prevalence of Thyroid Antibodies in Urban Population of Peninsular Malaysia
}

\author{
Shahar $M A^{a}$, Omar $A M^{b}, A B$ Wahab $N^{c}$, Sukor $N^{c}$, Kamaruddin $N A^{c}$ \\ ${ }^{a} A$ VISENA Specialist Hospital, Shah Alam, Selangor \\ bepartment of Internal Medicine, Kulliyyah of Medicine, International Islamic University Malaysia (IIUM), \\ Kuantan, Pahang \\ 'Endocrine Unit, Universiti Kebangsaan Malaysia Medical Centre (UKMMC), Kuala Lumpur
}

\section{ABSTRACT}

INTRODUCTION: Thyroid antibodies are closely related to autoimmune thyroid disorders. To date, there are no data on the prevalence of these antibodies among the Malaysian population. This study aimed to determine the prevalence of thyroid antibodies; and the factors associated with thyroid antibodies in the Malaysian adult population. MATERIALS AND METHODS: A cross-sectional study was performed in 5 preassigned regions in Peninsular Malaysia. Participants' sociodemographic profile and medical history were recorded. Physical examinations were done looking for abnormalities of the thyroid gland and signs of thyroid dysfunctions. Fifteen mils of blood were withdrawn and analysed for thyroid function, anti-thyroperoxidase (anti-TPO) and anti-thyroglobulin (anti-TG) antibodies at a central laboratory. RESULTS: Among the total of 2190 respondents, the overall prevalence of positive anti-TPO and anti-TG antibodies were $12.2 \%$ and $12.1 \%$, respectively; mainly found in urban and coastal areas. Only $7 \%$ to $9 \%$ of those with positive anti-TPO or antiTG antibodies had either hypo- or hyperthyroidism. The predictors for positive anti-TPO antibody were female [adjusted OR $1.7(95 \% \mathrm{Cl}: 1.2-2.4) ; \mathrm{p}=0.001$ ], Indian [adjusted $\mathrm{OR} 1.9(95 \% \mathrm{Cl}: 1.1-3.1) ; \mathrm{p}=0.020$ ], and having a goitre [adjusted OR $1.8(95 \% \mathrm{Cl}: 1.2-2.8), \mathrm{p}=0.004$ ]. The predictors of positive anti-TG antibody was female [adjusted OR $2.3(95 \% \mathrm{Cl}: 1.6-3.3) ; \mathrm{p}<0.001$ ], and having a goitre [adjusted $\mathrm{OR} 2.0(95 \% \mathrm{Cl}: 1.3-3.4)$, $\mathrm{p}=0.001]$. Those living in rural areas had $38 \%$ lower risk of having positive anti-TG. CONCLUSIONS: The prevalence of positive anti-TPO and anti-TG antibodies were $12.2 \%$ and $12.1 \%$, respectively; were higher among the urban and coastal populations. Those living in rural areas had lower risks of anti-TG antibody. (258 words)

KEYWORDS: anti-TG, anti-TPO

\section{INTRODUCTION}

Thyroid antibodies (anti-TPO and anti-TG) are used to help in the diagnosis of autoimmune thyroid disorders (AITD). Although the presence of anti-TPO and anti-TG suggest the diagnosis, the absence of these antibodies does not rule out AITD. Furthermore, patients with goitre of nonautoimmune origin, such as multinodular goitre and malignancy, have low titres of positive anti-TPO and anti-TG antibodies.

Corresponding Author:

Dr. Mohammad Arif Shahar

AVISENA Specialist Hospital

4, Jalan Ikhtisas, Seksyen 14

40000, Shah Alam, Selangor

Tel no : +6012-7802361

Email: arifshahar2013@gmail.com
Despite the limitation of use in the diagnosis, antiTPO and anti-TG antibodies are important in determining the prognosis of autoimmune thyroid disorders. Patients with Graves' disease with high titres of anti-TPO antibody would likely go into remission earlier comparables from those with high titers of anti-TG.

Having positive thyroid antibodies also has been associated with development of thyroid dysfunction. A landmark study, the Wickham follow-up study showed that female subjects with positive thyroid antibodies were 8 times at risk of spontaneous hypothyroidism compared from control even if their thyroid function were normal. ${ }^{1} \mathrm{Li}$ et al (2008) demonstrated that subjects who were anti-TPO and/ or anti-TG positive developed thyroid dysfunction more frequently compared from those without 
antibodies in a 5 -year prospective study. ${ }^{2}$

\section{MATERIALS AND METHODS}

\section{Objectives}

The objectives of this study were to determine the prevalence of anti-thyroperoxidase (anti-TPO) and anti-thyroglobulin (anti-TG) antibodies among the adult Malaysian population; and to determine the factors associated with the presence of these antibodies. A cross-sectional study was done between 2014 and 2016 in five pre-assigned regions, which were representative of the socioeconomic and geographical background in Malaysia.

\section{Study Population}

Malaysia is a country consisting of 14 states with 3 federal territories; located on a peninsular (West Malaysia) and Borneo Island (East Malaysia), separated by the South China Sea. The majority of the population resides in West Malaysia and is comprised of three major ethnic groups; namely the Malays (62\%), Chinese (21\%) and Indians (6\%). Most settlements were established along river banks and coastal areas. In terms of social-economy, $71 \%$ of Malaysia has been urbanized. ${ }^{3}$
Although ideal, conducting simple random sampling from a population of 31 million is both challenging and costly. Cluster sampling would incur less cost. However, it should involve numerous clusters in order to get ethnic and social-economical representation of the Malaysian population. Due to limited resources, we opted to do purposeful selection of five pre-assigned regions in Peninsular Malaysia are chosen based on their ethnic composition, geographical location and urbanization (socioeconomic status) to ensure samples are representative of Malaysian geo-socio-economic characteristics. These regions were located in the West of Peninsular Malaysia (Tanjung Karang and Kuala Selangor, in the state of Selangor - a rural and coastal area-where majority of the population were Malays and Indians); East of Peninsular Malaysia (Kuantan in the state of Pahang, an urban and coastal area, where majority of the population were Malays); Northern Peninsular Malaysia (Bidor in the state of Perak; a rural and in-land area, where majority of population were Chinese); Southern Peninsular Malaysian (Johor Bahru in the state of Johor - an urban and coastal area - where majority of population were Malays); and Central region (Subang Jaya in the Klang Valley - an urban and inland area - where majority population were Chinese and Indians) (Table I).

Table I: Socio-demography details of respondents based on regions selected

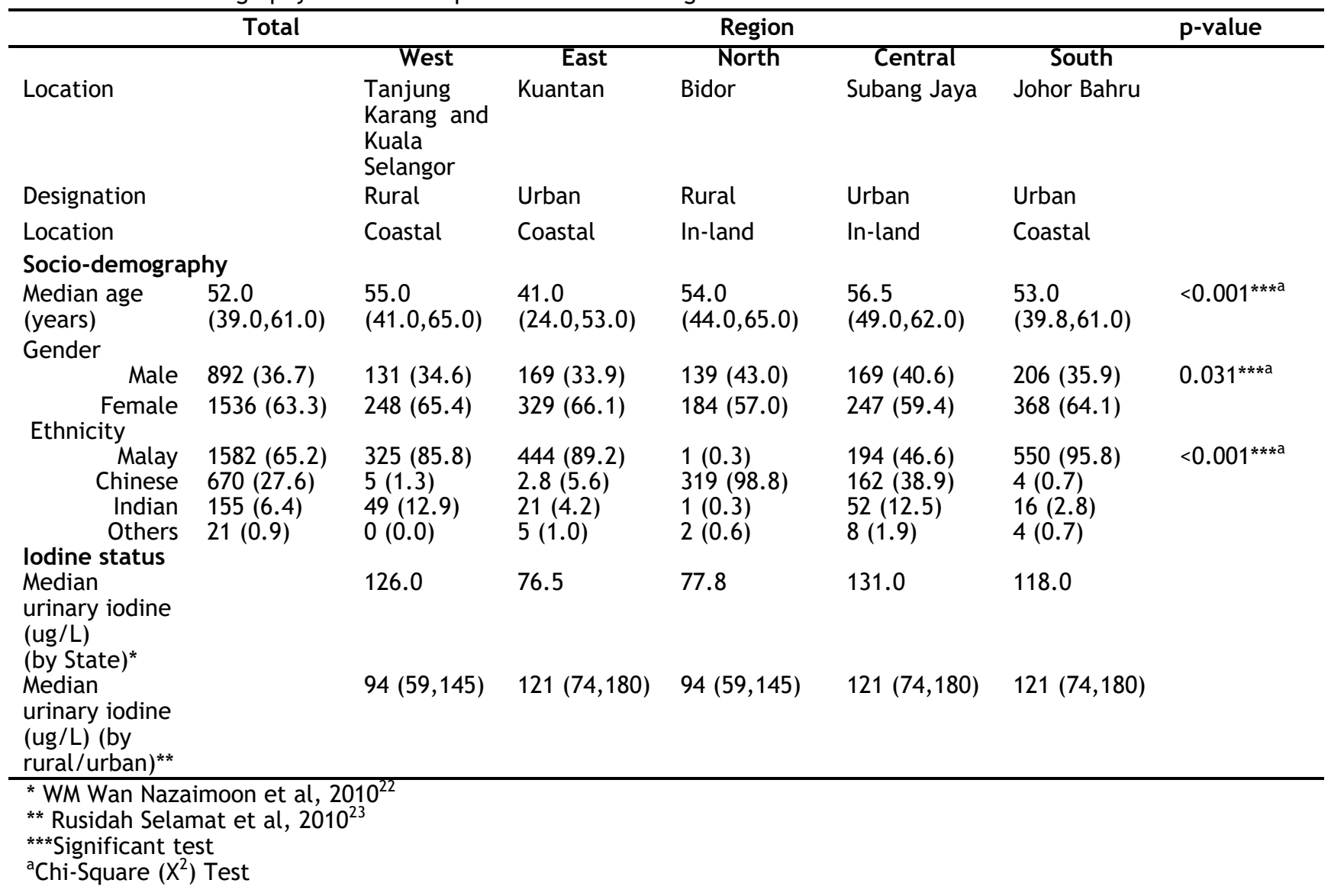


The sample size was calculated using OpenEpi online sample size calculator available at http:// www.openepi.com/SampleSize/SSPropor.htm. Since no previous data on thyroid antibodies are available, we used the prevalence of goitre; assuming that the real prevalence of thyroid antibodies resembles that of goitre. Based on the study done by Mafauzy et al., the prevalence of goitre in the State of Kelantan was $36.8 \%{ }^{4}$ Taking into account $50 \%$ response rate, the calculated sample size was 612 (confidence interval width is $\pm 5 \%$, confidence level $=80 \%$, estimated design effect $=2.0$ ).

\section{Data Collection}

All houses in a particular residential area in the preselected regions were included for sampling. Respondent from each household were selected by systematic random sampling using the KISH selection table adopted from the World Health Survey. ${ }^{5}$ Selected respondents were invited to a community centre in their respective area for data collection.

Physical examinations were done, paying attention in particular to the thyroid and signs of hypo- or hyperthyroidism. The diagnoses of goitre were made by palpation. Findings were corroborated by a repeat examination by a different investigator. The classification of thyroid swellings was done based on the World Health Organization (WHO) recommendations. ${ }^{6}$ Normal neck examination where the thyroid gland was neither palpable nor visible was classified as Grade- 0 . Grade- 1 goitre was defined as a goitre that was palpable, but not visible when the neck was in the normal position (i.e. the thyroid gland was not visibly enlarged). Nodules in a thyroid that was otherwise not enlarged fall into this category. Finally, Grade-2 goitre was a swelling in the neck that was clearly visible when the neck was in a normal position and was consistent with an enlarged thyroid gland when the neck was palpated. ${ }^{6}$

Fifteen mils of blood were withdrawn, centrifuged and aliquoted at the site of data collection. The aliquots were then transported to a central laboratory at the Universiti Kebangsaan Malaysia Medical Centre (UKMMC) for analysis. The hormonal assays and thyroid antibodies were performed using chemiluminescent microparticle immunoassays (CMIA) using the ARCHITECH 2000sr (Abbot) and IMMULITE $®$ i2000 (Siemens) systems respectively. Overt and subclinical hypothyroidism were defined as thyroid stimulating hormone $(\mathrm{TSH})>5.00 \mathrm{ulU} / \mathrm{mL}$ with free thyroxine (fT4) $<9.10 \mathrm{pmol} / \mathrm{L}$ and TSH $>5.00 \mathrm{ulU} / \mathrm{mL}$ with fT4 within the reference range $(9.10$ and $23.80 \mathrm{pmol} / \mathrm{L})$, respectively. Overt and subclinical hyperthyroidism was defined as TSH $<0.32 \mathrm{ulU} / \mathrm{mL}$ with $\mathrm{fT} 4$ above the reference range and TSH $<0.32$ $\mathrm{ulU} / \mathrm{mL}$ with fT4 within the reference range, respectively. Anti-TPO and anti-TG were considered as positive if the titre was more than $40 \mathrm{IU} / \mathrm{mL}$.

\section{Data Analysis}

We identified several populations to describe the prevalence of thyroid antibodies among Malaysian adult populations. The total prevalence of thyroid antibodies were determined in the total sample cohort [Total Population (TP), $n=2190]$. A subpopulation, known to have thyroid disease, goitre and/or on thyroid medication [Known Thyroid Disorder Population (KTDP), $n=136]$ were analysed to determine their thyroid function status, thyroid antibodies and goitre prevalence. Those without known thyroid disease, goitre and/or on thyroid medication were termed as Disease-Free Population (DFP), $\mathrm{n}=2054$ (Figure 1).

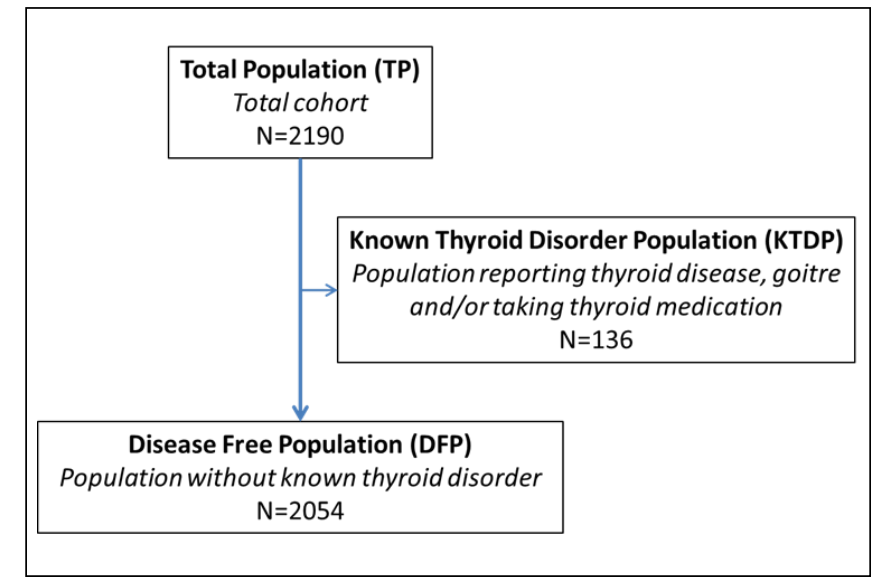

Figure 1: Definition of Total Population and its subpopulations

Statistical analysis was descriptive and exploratory. For the total population and sub-populations, all continuous variables were tested for normality using graphics such as histogram, box-plot and forest plot in addition to Kolmogorov-Smirnov test. Nonnormally distributed data was presented as median $\left(25^{\text {th }}, 75^{\text {th }}\right.$ centile). Bivariate analyses were done using $t$-test and Man Whitney-U test where appropriate. Finally, binary logistic regression was used to determine predictors for anti-TPO and antiTG antibodies. 


\section{Ethical Consideration}

This study was approved by the Medical Research and Ethics Committee (MREC) of University Kebangsaan Malaysia (UKM), Kuala Lumpur (Research Code: FF-2014-286) and the Medical Research Ethics Committee, Ministry of Health (Research Code: NMRR -13-1605-18629).

\section{RESULTS}

Prevalence of anti-TPO and anti-TG and its sociodemographic distribution

The prevalence of positive anti-TPO was $12.2 \%$ and anti-TG was $12.1 \%$ among the Total Population. Among those with known thyroid disorders, $39.0 \%$ and $30.1 \%$ had positive anti-TPO and anti-TG respectively.

Finally, among the Disease-Free Population, the prevalence of positive anti-TPO and anti-TG were $10.4 \%$ and $10.9 \%$ respectively (Table II).

Overall, female had higher prevalence of thyroid antibodies compared from male $(15.2 \%$ versus $3.0 \%$, p-value $<0.001$, for anti-TPO; and $15.7 \%$ versus $6.0 \%$, $\mathrm{p}$-value $<0.001$, for anti-TG). Females had higher prevalence of thyroid antibodies across all subpopulations. Age, on the other hand, did not differ between those with positive and negative thyroid antibodies (Table II).

In terms of ethnicity, Indians had significantly higher prevalence of anti-TPO in the Total Population as well as Disease-Free Population (20.9\% and 19.2\%, respectively). However the prevalence of positive anti-TPO was not significantly higher in Indians among those already known to have thyroid disorders. On the other hand, the prevalence of positive anti-TG was not statistically different between ethnicities either in the total cohort or subpopulations (Table II).

In the Total Population, the prevalence of positive anti-TPO was highest among those who resides in coastal and urban areas (12.1-16.1\%) compared to those in the rural, in-land area (9.0\%) $(\mathrm{p}=0.018)$. A similar trend was also seen in both those known to have thyroid disorders (KTDP) and Disease-Free Population; although not statistically significant.
The prevalence of positive anti-TG was also higher in coastal and urban areas (13.6-17.8\%) compared from rural, in-land areas $(9.6 \%)(\mathrm{p}<0.001)$ in the total cohort. Among the Disease-Free Population, similar findings with regards to anti-TG were observed (coastal and urban areas: $11.9-15.6 \%$ versus rural inland area: $8.9 \% ; \mathrm{p}=0.007$ ) (Table II).

The relationship between abnormal thyroid function, goitre and thyroid antibodies have been discussed in Table III.

\section{Predictors for positive anti-TPO}

In a multivariate regression analysis model where all factors were considered, the predictors for positive anti-TPO were female gender, Indian ethnicity, presence of goitre increased TSH and positive anti-TG (Table IV). Female were 1.7 times at higher risk of having positive anti-TPO compared to their male counterparts. Indian ethnicity was 1.9 times more likely to have positive anti-TPO compared to the Malay population. Thyroid specific factors such as goitre, TSH levels and positive anti-TG independently predicted positive anti-TPO.

Those who had goitre were 1.8 times more likely to have positive anti-TPO. Only an extra $4 \%$ of those with higher TSH have positive anti-TPO (OR $=1.04$, $95 \% \mathrm{Cl}=1.00-1.08, \mathrm{p}=0.046)$. Anti-TG, which was closely associated with autoimmune thyroid disorders, strongly predicted positive anti-TPO. Those with anti-TG positive were 10 times more likely to have positive anti-TPO; and it was the most important predictor in the equation (Table IV).

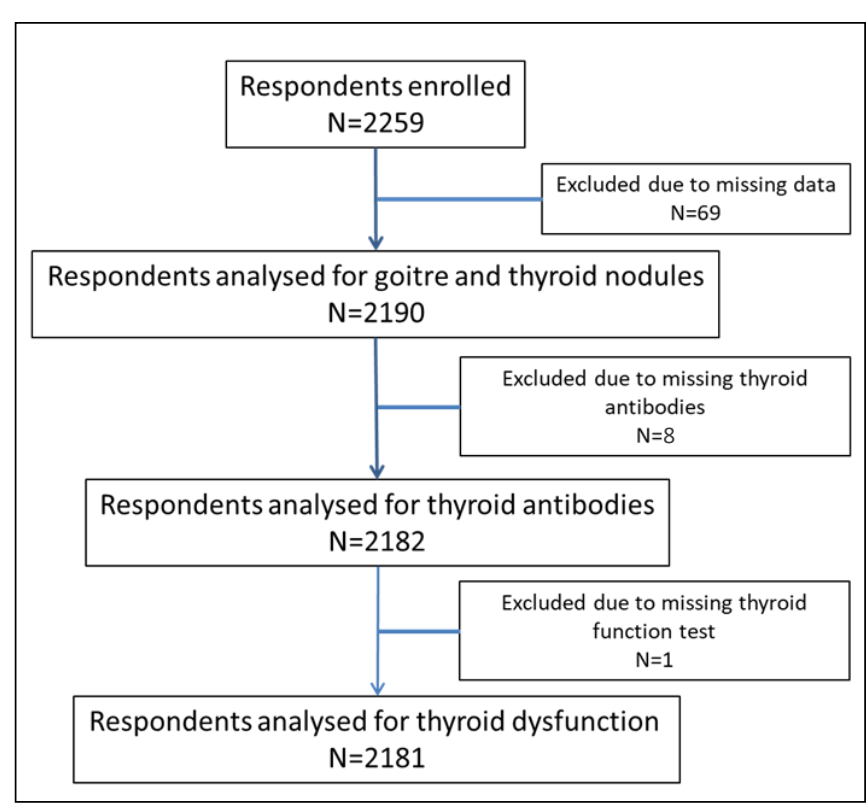

Figure 2: Respondents enrolled 
Table II: Prevalence of thyroid antibodies among Malaysian adult population

\begin{tabular}{|c|c|c|c|c|c|c|}
\hline & \multicolumn{6}{|c|}{ Thyroid antibodies } \\
\hline & \multicolumn{3}{|c|}{ Anti-TPO } & \multicolumn{3}{|c|}{ Anti-TG } \\
\hline & Negative & Positive & p-value & Negative & Positive & p-value \\
\hline $\begin{array}{l}\text { Total Population } \\
\text { (TP) }\end{array}$ & $1916(87.7)$ & $266(12.2)$ & & $1918(87.9)$ & $264(12.1)$ & \\
\hline Age & $\begin{array}{l}52.0 \\
(39.0,61.0)\end{array}$ & $\begin{array}{l}53.0 \\
(43.0,61.0)\end{array}$ & $0.259^{a}$ & $\begin{array}{l}52.0 \\
(38.0,61.0)\end{array}$ & $\begin{array}{l}54.0 \\
(43.3,61.0)\end{array}$ & $0.068^{\mathrm{a}}$ \\
\hline Male & $754(93.0)$ & $57(3.0)$ & $<0.001^{* a}$ & $762(94.0)$ & $49(6.0)$ & $<0.001^{*}$ \\
\hline Female & $1162(84.8)$ & $209(15.2)$ & & $1156(84.3)$ & $215(15.7)$ & \\
\hline Malay & $1329(88.2)$ & $177(11.8)$ & $0.012^{* a}$ & $1331(88.4)$ & $175(11.6)$ & $0.625^{\mathrm{a}}$ \\
\hline Chinese & $461(89.0)$ & $57(11.0)$ & & $452(87.3)$ & $66(12.7)$ & \\
\hline Indian & $110(79.1)$ & $29(20.9)$ & & $118(84.9)$ & $21(15.1)$ & \\
\hline Others & $16(84.2)$ & $3(15.8)$ & & 17 (89.5) & $2(10.5)$ & \\
\hline Region & & & & & & \\
\hline $\begin{array}{l}\text { Tanjung Karang and } \\
\text { Kuala Selangor (West) }\end{array}$ & $340(90.4)$ & $36(9.6)$ & $0.018^{* a}$ & 344 (91.5) & $32(8.5)$ & $<0.001^{* a}$ \\
\hline Kuantan (East) & $436(87.9)$ & $60(12.1)$ & & $447(90.1)$ & $49(9.9)$ & \\
\hline Bidor (North) & $294(91.0)$ & $29(9.0)$ & & $292(90.4)$ & $31(9.6)$ & \\
\hline Subang Jaya (Central) & $348(83.9)$ & $67(16.1)$ & & $341(82.2)$ & $74(17.8)$ & \\
\hline Johor Bahru (South) & $498(87.1)$ & 74 (12.9) & & $494(86.4)$ & $78(13.6)$ & \\
\hline $\begin{array}{l}\text { Known Thyroid } \\
\text { Disorder } \\
\text { Population (KTDP) }\end{array}$ & $83(61.0)$ & $53(39.0)$ & & 95 (69.9) & $41(30.1)$ & \\
\hline $\begin{array}{l}\text { Age } \\
\text { Gender }\end{array}$ & $\begin{array}{l}55.0 \\
(45.0,63.0)\end{array}$ & $\begin{array}{l}52.0 \\
(40.0,60.0)\end{array}$ & $0.150^{\mathrm{a}}$ & $\begin{array}{l}52.0 \\
(44.3,63.0)\end{array}$ & $\begin{array}{l}54.0 \\
(42.5,61.0)\end{array}$ & $0.563^{\mathrm{a}}$ \\
\hline Male & $12(57.1)$ & 9 (92.9) & $0.434^{\mathrm{a}}$ & $14(66.7)$ & 7 (33.3) & $0.456^{\mathrm{a}}$ \\
\hline Female & $71(61.7)$ & $44(38.3)$ & & $81(70.4)$ & $34(29.6)$ & \\
\hline $\begin{array}{r}\text { Malay } \\
\text { Chinese }\end{array}$ & $\begin{array}{l}56(61.5) \\
18(58.1)\end{array}$ & $\begin{array}{l}35(38.5) \\
13(41.9)\end{array}$ & $0.911^{\mathrm{a}}$ & $\begin{array}{l}66(72.5) \\
19(61.3)\end{array}$ & $\begin{array}{l}25(27.5) \\
12(38.7)\end{array}$ & $0.495^{\mathrm{a}}$ \\
\hline Indian & $9(64.3)$ & $5(35.7)$ & & $10(71.4)$ & $4(28.6)$ & \\
\hline Others & - & - & & - & - & \\
\hline Region & & & & & & \\
\hline $\begin{array}{l}\text { Tanjung Karang and } \\
\text { Kuala Selangor (West) }\end{array}$ & $14(66.7)$ & $7(33.3)$ & $0.226^{\mathrm{a}}$ & $19(90.5)$ & $2(9.5)$ & $0.198^{\mathrm{a}}$ \\
\hline Kuantan (East) & $11(55.0)$ & $9(45.0)$ & & $14(70.0)$ & $6(30.0)$ & \\
\hline Bidor (North) & $6(75.0)$ & $2(25.0)$ & & $5(62.5)$ & $3(37.5)$ & \\
\hline Subang Jaya (Central) & $18(47.4)$ & $20(52.6)$ & & $23(60.5)$ & $15(39.5)$ & \\
\hline Johor Bahru (South) & $34(69.4)$ & $15(30.6)$ & & $34(69.9)$ & $15(30.6)$ & \\
\hline $\begin{array}{l}\text { Disease-Free } \\
\text { Population (DFP) }\end{array}$ & $1834(89.6)$ & $213(10.4)$ & & $1824(89.1)$ & $223(10.9)$ & \\
\hline Age & $\begin{array}{l}52.0 \\
(38.0,61.0)\end{array}$ & $53.0(43.0,61.5)$ & 0.130 & $52.0(38.0,61.0)$ & $\begin{array}{l}54.0 \\
(44.0,62.0)\end{array}$ & $0.043^{*}$ \\
\hline Gender & $741(93.8)$ & $49(6.2)$ & $<0.001^{* a}$ & $747(94.6)$ & $43(5.4)$ & $<0.001^{* a}$ \\
\hline Female & $1093(87.0)$ & $164(13.0)$ & & 1077 (85.7) & $180(14.3)$ & \\
\hline Ethnicity & & & & & & \\
\hline Malay & $1274(90.0)$ & $142(10.0)$ & $0.007^{* a}$ & $1266(89.4)$ & $150(10.6)$ & $0.778^{\mathrm{a}}$ \\
\hline Chinese & $443(91.0)$ & $44(9.0)$ & & $433(88.9)$ & $54(11.1)$ & \\
\hline Indian & $101(80.8)$ & $24(19.2)$ & & $108(86.4)$ & $17(13.6)$ & \\
\hline Others & $16(84.2)$ & $3(15.8)$ & & $17(89.5)$ & $2(10.5)$ & \\
\hline Region & & & & & & \\
\hline $\begin{array}{l}\text { Tanjung Karang and } \\
\text { Kuala Selangor (West) }\end{array}$ & $326(91.6)$ & $30(8.4)$ & $0.324^{\mathrm{a}}$ & $325(91.3)$ & $31(8.7)$ & $0.007^{* a}$ \\
\hline Kuantan (East) & $425(89.3)$ & $51(10.7)$ & & $433(91.0)$ & $43(9.0)$ & \\
\hline Bidor (North) & $288(91.4)$ & $27(8.6)$ & & $287(91.1)$ & $28(8.9)$ & \\
\hline Subang Jaya (Central) & $330(87.5)$ & $47(12.5)$ & & $318(84.4)$ & $59(15.6)$ & \\
\hline Johor Bahru (South) & $465(88.9)$ & $58(11.1)$ & & $461(88.1)$ & $62(11.9)$ & \\
\hline
\end{tabular}

${ }^{\mathrm{a}}$ Chi Square $\left(\mathrm{X}^{2}\right)$ Test

*Significant association 
Indians were not at increased risk of having positive

The predictors of positive anti-TG were older age anti-TG. Interestingly, those living in rural areas had group, female gender, living in urban areas, presence had goitre were nearly twice likely to have positive of goitre, elevated TSH and positive anti-TPO. These anti-TG. Although the relationship was statistically variables predicted $27 \%$ of positive anti-TG. With significant, those with higher TSH levels had only an every logit increment of age, there was an extra $2 \%$ extra $6 \%$ risk of having positive anti-TG. Finally, increase in positive anti-TG. Female were 2.3 times those with positive anti-TPO were 10 times at risk of more likely to have positive anti-TG compared from having positive anti-TG as well (Table IV).

the male gender. In contrary to positive anti-TPO,

Table III: Relationship between thyroid dysfunction and thyroid antibodies

\begin{tabular}{|c|c|c|c|c|c|c|}
\hline & \multicolumn{6}{|c|}{ Thyroid antibodies } \\
\hline & \multicolumn{3}{|c|}{ Anti-TPO } & \multicolumn{3}{|c|}{ Anti-TG } \\
\hline & Negative & Positive & p-value & Negative & Positive & p-value \\
\hline $\begin{array}{l}\text { Total Population } \\
\text { (TP) }\end{array}$ & $1909(87.9)$ & $264(12.1)$ & & $1909(87.9)$ & $264(12.1)$ & \\
\hline Euthyroid & $1833(89.2)$ & $222(10.8)$ & $<0.001^{* a}$ & $1832(89.1)$ & $223(10.9)$ & $<0.001^{* a}$ \\
\hline Hypothyroid & $6(54.5)$ & $5(45.5)$ & & $6(54.5)$ & $5(45.5)$ & \\
\hline Subclinical hy- & $21(61.8)$ & $13(38.2)$ & & $20(58.8)$ & $14(41.2)$ & \\
\hline Hyperthyroid & $3(25.0)$ & $9(75.0)$ & & $6(50.0)$ & $6(50.0)$ & \\
\hline $\begin{array}{l}\text { Subclinical } \\
\text { hyperthyroid }\end{array}$ & $46(75.4)$ & $15(24.6)$ & & $45(73.8)$ & $16(26.2)$ & \\
\hline $\begin{array}{l}\text { Known Thyroid } \\
\text { Disorder } \\
\text { Population (KTDP) }\end{array}$ & $80(60.6)$ & $52(39.4)$ & & 91 (68.9) & $41(31.1)$ & \\
\hline Euthyroid & $54(64.3)$ & $30(35.7)$ & 0.144 & $56(66.7)$ & $28(33.3)$ & $0.571^{\mathrm{a}}$ \\
\hline Hypothyroid & $2(40.0)$ & $3(60.0)$ & & $4(80.0)$ & $1(20.0)$ & \\
\hline $\begin{array}{l}\text { Subclinical hy- } \\
\text { pothyroid }\end{array}$ & 7 (63.6) & $4(36.4)$ & & $9(81.8)$ & $2(18.2)$ & \\
\hline Hyperthyroid & $3(27.3)$ & $8(72.7)$ & & $6(54.5)$ & $5(45.5)$ & \\
\hline $\begin{array}{l}\text { Subclinical } \\
\text { hyperthyroid }\end{array}$ & $14(66.7)$ & $7(33.3)$ & & $16(76.2)$ & $5(23.8)$ & \\
\hline $\begin{array}{l}\text { Disease-Free } \\
\text { Population (DFP) }\end{array}$ & $1830(89.6)$ & $212(10.4)$ & & $1819(89.1)$ & $223(10.9)$ & \\
\hline Euthyroid & $1781(90.3)$ & $191(9.7)$ & $<0.001^{* a}$ & $1778(90.2)$ & $194(9.8)$ & $<0.001^{* a}$ \\
\hline Hypothyroid & $3(50.0)$ & $3(50.0)$ & & $1(16.7)$ & $5(83.3)$ & \\
\hline $\begin{array}{l}\text { Subclinical } \\
\text { pothyroid }\end{array}$ & $14(60.9)$ & $9(39.1)$ & & $11(47.8)$ & $12(52.2)$ & \\
\hline Hyperthyroid & $0(0.0)$ & $1(100.0)$ & & $0(0.0)$ & $1(100.0)$ & \\
\hline $\begin{array}{l}\text { Subclinical } \\
\text { hyperthyroid }\end{array}$ & $32(80.0)$ & $8(20.0)$ & & $29(72.5)$ & $11(27.5)$ & \\
\hline
\end{tabular}

${ }^{\mathrm{a} C h i-S q u a r e}\left(\mathrm{X}^{2}\right)$ test

*Significant association

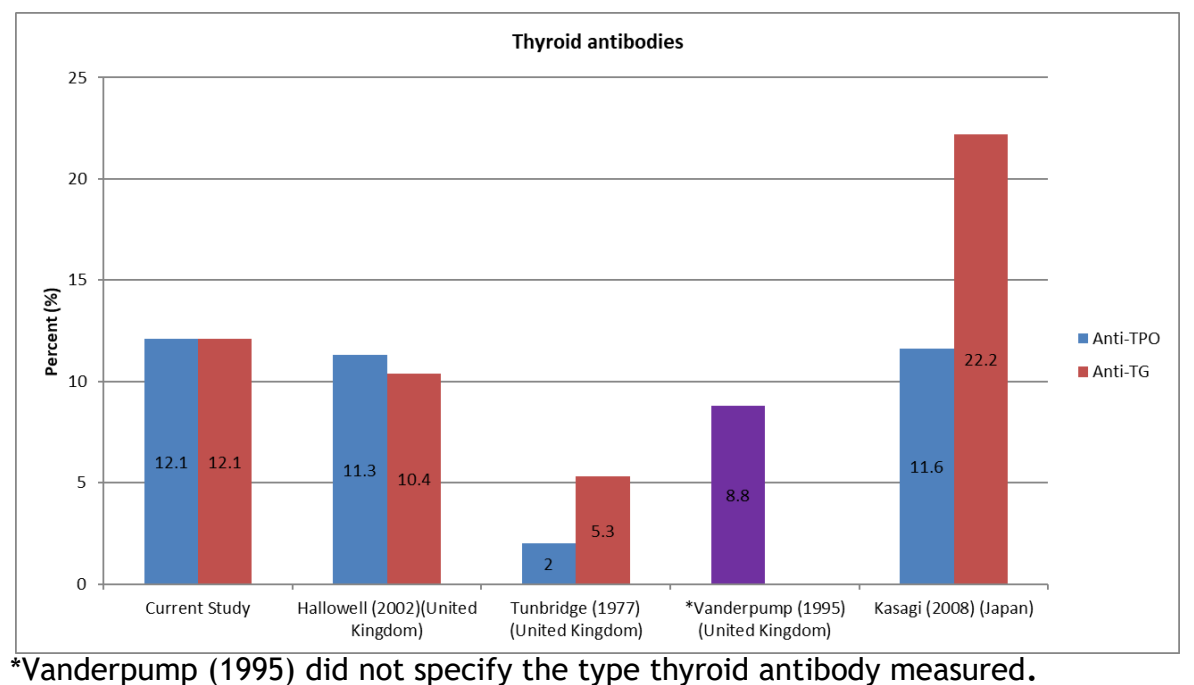

Figure 3: Comparison of the prevalence of thyroid antibodies in selected studies. 
Table IV: Multivariate regression analysis for predictors of positive anti-TPO and positive anti-TG

\begin{tabular}{|c|c|c|c|c|c|c|c|c|}
\hline \multirow[b]{2}{*}{ Variables } & \multicolumn{4}{|c|}{$\begin{array}{l}\text { Predictors for anti-TPO adjusted for all } \\
\text { variables }^{\mathrm{a}}\end{array}$} & \multicolumn{4}{|c|}{$\begin{array}{l}\text { Predictors for anti-TG adjusted for all } \\
\text { variables }\end{array}$} \\
\hline & OR & $\begin{array}{l}95 \% \mathrm{Cl} \\
\text { Lower }\end{array}$ & Upper & p-value & OR & $\begin{array}{l}95 \% \mathrm{CI} \\
\text { Lower }\end{array}$ & Upper & p-value \\
\hline Age & 1.009 & 0.998 & 1.019 & 0.099 & 1.016 & 1.006 & 1.027 & $0.003^{*}$ \\
\hline Female & 1.731 & 1.235 & 2.425 & $0.001^{*}$ & 2.347 & 1.646 & 3.349 & $0.000^{*}$ \\
\hline Malay & & & & 0.088 & & & & 0.823 \\
\hline Chinese & 0.936 & 0.563 & 1.555 & 0.797 & 0.951 & 0.575 & 1.573 & 0.846 \\
\hline Indian & 1.858 & 1.103 & 3.129 & $0.020^{*}$ & 0.782 & 0.426 & 1.436 & 0.428 \\
\hline Others & 1.494 & 0.351 & 6.361 & 0.587 & 0.611 & 0.112 & 3.316 & 0.568 \\
\hline Rural & 0.723 & 0.509 & 1.028 & 0.071 & 0.619 & 0.432 & 0.888 & $0.009^{*}$ \\
\hline Coastal & 0.996 & 0.657 & 1.508 & 0.984 & 0.728 & 0.479 & 1.107 & 0.138 \\
\hline Overweight & & & & 0.467 & & & & 0.253 \\
\hline Underweight & 0.613 & 0.255 & 1.476 & 0.275 & 1.202 & 0.552 & 2.621 & 0.643 \\
\hline Normal & 0.883 & 0.621 & 1.256 & 0.489 & 1.334 & 0.945 & 1.884 & 0.101 \\
\hline $\begin{array}{l}\text { Goitre } \\
\text { present }\end{array}$ & 1.843 & 1.221 & 2.781 & $0.004^{*}$ & 1.995 & 1.319 & 3.017 & $0.001^{*}$ \\
\hline TSH (ulU/mL) & 1.04 & 1.001 & 1.081 & $0.046^{*}$ & 1.065 & 1.021 & 1.111 & $0.004^{*}$ \\
\hline $\begin{array}{l}\text { Anti-TG } \\
\text { positive }\end{array}$ & 10.018 & 7.338 & 13.678 & $0.000^{*}$ & - & - & - & - \\
\hline $\begin{array}{l}\text { Anti-TPO } \\
\text { positive }\end{array}$ & - & - & - & - & 10.009 & 7.331 & 13.665 & $0.000^{*}$ \\
\hline Constant & 0.034 & & & 0.000 & 0.021 & & & 0.000 \\
\hline
\end{tabular}

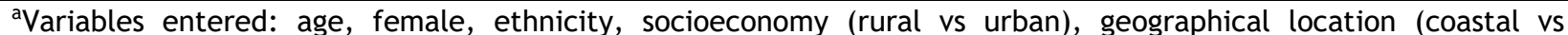
inland), body mass index (BMI), palpable thyroid nodule, goitre, TSH, anti-TG positive (Nagelkerke $r^{2}=0.249$, Hosmer Lemeshow, $p=0.141$ )

bariables entered: age, female, ethnicity, socioeconomy (rural vs urban), geographical location (coastal vs inland), body mass index (BMI), palpable thyroid nodule, goitre, TSH, anti-TPO positive (Nagelkerke $r^{2}=0.272$, Hosmer Lemeshow, $p=0.046)$, *statistically significant

\section{DISCUSSION}

Prevalence of thyroid antibodies and comparison with selected studies.

To the best of our knowledge, this was the first study in Malaysia looking at the prevalence of thyroid antibodies in the adult population. The overall prevalence of positive anti-TPO and anti-TG antibodies were $12.2 \%$ and $12.1 \%$, respectively. Among the Disease-Free Population, the prevalence of positive anti-TPO and anti-TG were $10.4 \%$ and $10.9 \%$, respectively. Among the subjects with known thyroid disease, the prevalence of anti-TPO and antiTG were $39.0 \%$ and $30.1 \%$, respectively.

The prevalence of thyroid antibodies in this study was comparable with those reported in several studies. Earlier studies done in the UK reported a lower prevalence of thyroid antibodies. It was possible that the assays used contributed to the low detection of thyroid antibodies. Before the 1980's, thyroid antibody assays were directed towards detecting anti-microsomal antibodies prior to identification of thyroperoxidase antigen and its antibody. The prevalence of anti-TG was much lower compared from a study reported in Japan, were

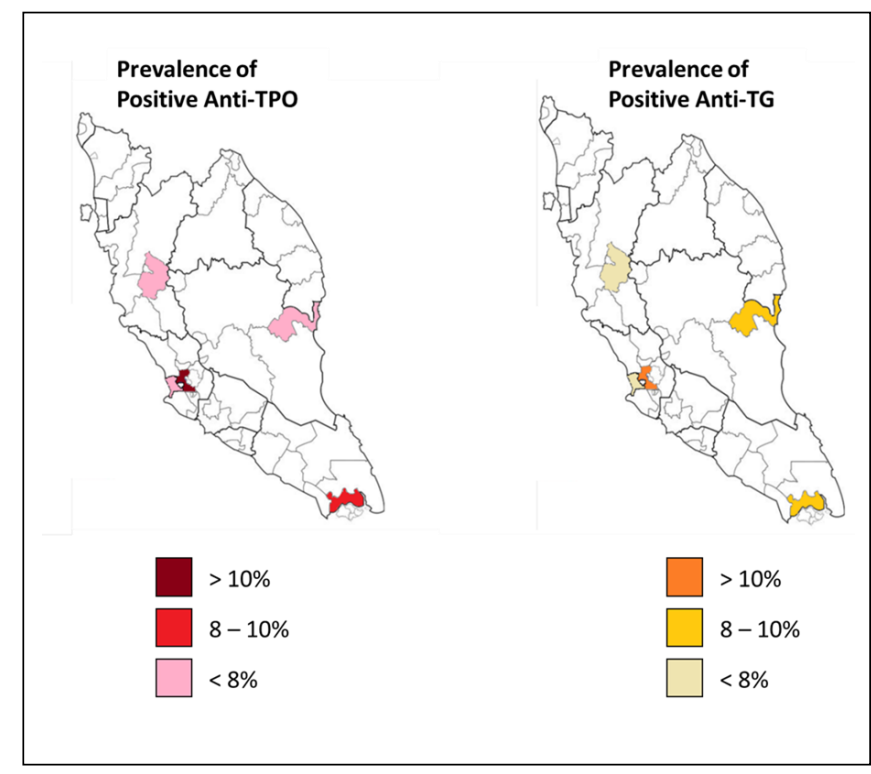

Figure 4: The prevalence of anti-TPO and anti-TG according to sampled regions

iodine exposure was generally higher. Other possible explanation to the differences to the prevalence was the variable cut-of level of thyroid antibodies used in various studies despite using similar assays systems. ${ }^{2,7-9}$ The differences of prevalence of thyroid antibodies between selected studies are illustrated in Figure 3. 
Prevalence of thyroid antibodies and sociodemographic characteristics.

In areas located in coastal and urban regions, higher prevalence of thyroid antibodies were recorded which may be indicative of sufficient iodine exposure (Figure 4). A significant number of goitre was also found in these areas. This suggests that the goitre in these areas were of autoimmune aetiology (i.e. Graves' disease and Hashimoto's thyroiditis). The finding of a higher prevalence of thyroid antibodies in areas where iodine is readily available was consistent with other studies. Delitala et al. (2014) reported a high prevalence of at least one thyroid antibodies (either anti-TPO or anti-TG) in the iodine sufficient population of Sardinia. ${ }^{8}$ In addition to that, Li et al. (2008) eloquently demonstrated that high iodine exposure was a risk factor for hypothyroidism and antibody positive in a prospective study comparing areas of different iodine intake. ${ }^{2}$

Female gender was associated with high prevalence of anti-TPO and anti-TG in the Total and Disease-Free Populations. The influence of gender demonstrated in this study was consistent with previous reports. ${ }^{1,7,8,10-13}$ Age did not influence the rate of positive thyroid antibodies. This was contrary to other reports. Yan et al (2015) reported that older age was one of the factors that predicts the positivity of anti-TPO. ${ }^{13}$ Similarly, the NHANES III study and Delitala et al (2014) demonstrated that the prevalence of thyroid antibodies increased with age. $^{8,12}$

The variation of thyroid antibodies prevalence among different ethnic group was observed in our cohort. The prevalence of anti-TPO was higher in Indian population compared from other ethnicity in the Total and Disease-Free Populations compared from other ethnicities. Similarly, Hollowell et al. (2002) demonstrated variable prevalence of thyroid antibodies in subjects of different ethnic background. ${ }^{12}$

Although they reside in the same areas (i.e. same iodine exposure), the difference in prevalence of thyroid antibodies between ethnic groups indicates that there may be inherent genetic risks involved. Delitala et al. (2012) suggested that only those who had a genetic susceptibility were at higher risk of developing thyroid dysfunction with thyroid antibodies. $^{8}$
Risk predictors for thyroid antibodies.

This study also elucidated the risk of having positive thyroid antibodies in the Malaysian adult population. The risk factors for having positive anti-TPO were female gender, Indian ethnicity, the presence of goitre, higher TSH levels and positive anti-TG. The presence of anti-TG was predicted by older age, female gender, living in urban areas, having a goitre and positive anti-TPO. It is worth mentioning that, the only geographical factor which had an influence on positive thyroid antibodies (anti-TG) was living in urban areas.

Assuming that urban and coastal areas are exposed to higher iodine levels compared to rural and in-land areas, this finding was consistent with the postulation that higher exposure of iodine was associated with the presence of positive anti-TG. Furthermore, in previous studies, areas designated as urban have been shown to have higher levels of urinary iodine excretion. ${ }^{14}$

\section{Clinical implications and study limitations.}

There were consistent signals that areas in the coastal and urban areas of Peninsular Malaysia exhibit higher prevalence of thyroid antibodies; there may be excessive exposure to iodine in these areas which needs clarification.

In the public health perspective, those living in coastal and urban areas might be at higher risk of autoimmune thyroid disorders by virtue of higher rate of positive antibodies. Having said that, the value of public screening for these antibodies in the community remains low in view of the lack of evidence for treatment for those with positive thyroid antibodies without thyroid dysfunction. However, it would be of interest to see whether the respondents with positive antibodies will continue to develop thyroid dysfunction in the future.

Although data from this study is useful, some limitations need to be considered. The high prevalence of anti-TPO among the Indian population may be related to the sampling method employed. Although random sampling was used for each location, the regions were selected purposively according to ethnicity and socioeconomic strata (urban versus rural) where majority of ethnicity are found in certain areas. Therefore, the prevalence of 
anti-TPO in Indians might not be representative of the general Malaysian population.

Secondly, iodine, which is an important factor for autoimmunity and subsequent development of thyroid antibodies, was not measured due to cost and logistic issues.

Despite these limitations, the data provided serves as a baseline for future study in determining the incidence and risk of thyroid disorders among those with positive thyroid antibodies.

\section{CONCLUSIONS}

The prevalence of anti-TPO and anti-TG antibodies in this population was $12.2 \%$ and $12.1 \%$ respectively. Higher prevalence of thyroid antibodies was observed in female and Indians. Females are at higher risk of positive thyroid antibodies. Indians were at higher risk of anti-TPO antibody but not anti-TG antibody. The higher prevalence of thyroid antibodies in urban areas may be a reflection of iodine availability. Living in a rural area was associated with lower risk of having anti-TG antibody.

\section{ACKNOWLEDGMENT}

The Malaysian Endocrine Disorders (MyENDO) Study Group: Kuck Meng CHONG (Klinik Chong), Hanita OTHMAN (UKMMC), Kwa Siew KIM (International Medical University-IMU), G R Letchuman RAMANATHAN (Hospital Taiping), Huai Heng LOH (Universiti Malaysia Sarawak-UNIMAS), Luqman IBRAHIM (University of Malaya-UM), Norhaliza MOHD ALI (Hospital Sultanah Aminah- HSA), CP OOI (Universiti Putra Malaysia-UPM), Subashini RAJOO (Hospital Kuala Lumpur), Wan Juani WAN SEMAN (Hospital Putrajaya), Yusniza YUSOFF (Hospital Sungai Buloh) and Zanariah HUSSEIN (Hospital Putrajaya).

The study was funded by the Malaysian Endocrine and Metabolic Society (MEMS).

\section{REFERENCES}

1. Vanderpump MPJ, Tunbridge WM., Evanst JG, et al. The incidence of thyroid disorders in the communitya: a twenty-year follow-up of the Whickham Survey. Clin Endocrinol (Oxf) 1995; 43:55-68.
2. Li Y, Teng D, Shan Z, et al. Antithyroperoxidase and antithyroglobulin antibodies in a five-year follow-up survey of populations with different iodine intakes. J Clin Endocrinol Metab 2008; 93:1751-1757.

3. Department of Statistics. Population and Housing Census of Malaysia 2010. Dep Stat Malaysia 2011: 77.

4. Mafauzy M, Musalmah M. The Prevalence of Endemic Goitre in Kelantan, Malaysia. Med J Malaysia 1993; 48:64-70.

5. World Health Organisation. WORLD HEALTH SURVEY C-Appendices (KISH tables, Vignettes, Cards 2002.

6. World Health Organisation. Goitre as a determinant of the prevalence and severity of iodine deficiency disorders in populations 2014: 14-19.

7. Kocak M, Erem C, Deger O, et al. Current prevalence of goiter determined by ultrasonography and associated risk factors in a formerly iodine-deficient area of Turkey. Endocrine 2014; 47:290-298.

8. Delitala AP, Pilia MG, Ferreli L, et al. Prevalence of unknown thyroid disorders in a Sardinian cohort. Eur J Endocrinol 2014; 171:143-149.

9. Liu Y, Huang H, Zeng J, Sun C. Thyroid volume, goiter prevalence, and selenium levels in an iodine-sufficient area: a cross-sectional study. BMC Public Health 2013; 13:1153.

10. Kasagi K, Takahashi N, Inoue G, et al. Thyroid function in Japanese adults as assessed by a general health checkup system in relation with thyroid-related antibodies and other clinical parameters. Thyroid 2009; 19:937-944.

11. Bjùro $\mathrm{T}$, Holmen $\mathrm{J}$, Kruger $\mathrm{O}$, et al. Prevalence of thyroid disease, thyroid dysfunction and thyroid peroxidase antibodies in a large, unselected population. The Health Study of Nord-Trùndelag ( HUNT ). Eur J Endocrinol 2000; 143:639-647.

12. Hollowell J, Staehling N, Flanders W, et al. Serum TSH, T 4, and Thyroid Antibodies in the United States Population (1988 to 1994): National Health and Nutrition Examination Survey (NHANES III). J Clin Endocrinol Metab 2002; 87:489-499.

13. Yan $\mathrm{Y}-\mathrm{R}$, Gao X-L, Zeng J, et al. The association between thyroid autoantibodies in serum and abnormal function and structure of the thyroid. J Int Med Res. 2015; 43:412-423. 
14. Selamat R, Wan Mohamud WN, Zainuddin AA, Rahim NSCA, Ghaffar SA, Aris T. lodine deficiency status and iodised salt consumption in Malaysia: Findings from a national iodine deficiency disorders survey. Asia Pac J Clin Nutr 2010; 19:578-585. 